Plant Production Science

http:/www.journals.zu.edu.eg/journalDisplay.aspx?Journalld=1\&queryType=Master

\title{
EFFECT OF FOLIAR SPRAY WITH AQUEOUS EXTRACT OF DATE PALM POLLEN GRAINS AND LITHOVIT ON COMMON BEAN PLANTS UNDER DIFFERENT IRRIGATION LEVELS
}

\author{
Usrya A.I. Byan*
}

Veg. Res. Dept., Hort. Res. Inst., Agric. Res. Cent., Giza, Egypt

\section{Received: 03/03/2020 ; Accepted: 03/05/2020}

\begin{abstract}
Two field experiments were carried out during two successive seasons of 2017 and 2018 at the Experimental Farm of Kaha Station, Qalubia Governorate, Egypt. The study investigated the effect of three irrigation levels $(50 \%, 75 \%$ and 100\%) from crop evapotraspiration (ETc) and five foliar spray treatments by aqueous extract of date palm pollen grains at 1,3 and $5 \mathrm{~g} / 1$, lithovit at $1 \mathrm{~g} / 1$ and tap water (control) on common bean plants c.v. Nebraska. The effect of treatments on growth, seed yield, chemical characters as well as water use efficiency were studied. The recorded results illustrated that the plants sprayed by date palm pollen grains extract at $5 \mathrm{~g} / 1$ and irrigated by $100 \%$ $\left(968.72 \mathrm{~m}^{3}\right.$ water/fad.) or $75 \%\left(726.54 \mathrm{~m}^{3}\right.$ water/fad.) of irrigation water, gave the highest values of all vegetative growth parameters. On the other hand, the plants sprayed with date palm pollen grains extract at 1,3 or $5 \mathrm{~g} / 1$ followed by lithovit at $1 \mathrm{~g} / 1$, respectively and irrigated by $100 \%$ or $75 \%$ of irrigation water gave the highest value for each of number of pods/plant, weight of 1000 seeds and total dry seed yield ton/fad., compared to the control, i.e. water foliar spray treatment in both growing seasons. Water use efficiency (WUE) decreased when the amount of irrigation water increased to $100 \%$ ETc and the highest values were obtained from $50 \%$ treatment followed by $75 \%$ Etc. Moreover, the plants sprayed with date palm pollen grains extract at 5,3 or $1 \mathrm{~g} / 1$, respectively, followed by lithovit at $1 \mathrm{~g} / \mathrm{L}$ (nano-fertilizer) showed the highest values of WUE. Generally, it can recommend by spraying common bean plants by date palm pollen grains extract at $(5,3$ or $1 \mathrm{~g} / \mathrm{l})$ respectively, followed by lithovit at $1 \mathrm{~g} / 1$ (nano-fertilizer) with irrigation at level of $75 \%$ from ETc to obtain the highest seed yield with the best quality and the favorable water use efficiency at the same time saving $25 \%$ from water irrigation quantity.
\end{abstract}

Key words: Phaseolus vulgaris, date palm pollen grains, lithovit, seed yield and water use efficiency.

\section{INTRODUCTION}

Common bean (Phaseolus vulgaris L.) belongs to the legume family (Leguminosae). It is widely cultivated and represents one of the largest food components in Africa which valued for its high content of protein and micronutrients such as iron and folic acid. It is one of the most economically important crops in Egypt and provides an income source for small farmers. It does not consume large amounts of fertilizer, plus it is consider short season crop, as well as, it is one of the crops that cause soil fertility or neither consumes nor depletes soil nutrients. It's

\footnotetext{
*Corresponding author: Tel. : +201224317589

E-mail address: drusrya@hotmail.com
}

also one of the few vegetable crops that can be grown with particularly described it for either local consumption or exportation. It is considered optimum warm-season crop, sensitive to temperature extremes and irrigation (drought or flooding).

Nowadays, there is a critical need to balance water availability, water requirements and water consumption, thus water conserving is becoming a decisive consideration for agriculture, whereas water is the main limiting factor for plant growth. Moreover, plants are prodigal in the water use because only roughly $5 \%$ of water 
uptake is used for its growth and development while the remaining $95 \%$ is lost through transpiration and leaching (Prakash and Ramachandran, 2000). Agriculture is the largest water consumer worldwide, whereas it using $70 \%$ of the total renewable fresh water resources, as reported by WWAP (2014). Climate change has forced scientists and decision makers to think about the future of water resources and their sustainability in a scarcity situation, taking into account less water coming from Ethiopia to Egypt and at the same time a high rate of human population increasing quickly (Quda, 2016). Water resources are a scarce and limiting factor for expanding cultivation and plant production in many arid and semi-arid areas, including Egypt. Environmental stresses and climate change impact agricultural production and the food supply, all that causes of crop losses, reducing average yields for most major crops by more than 50\% (Bisbis et al., 2018). In addition, improving as well as enhancing water use efficiency (WUE) it is very important, without any reduction in productivity to satisfy present and future requirements of a high population growth rate which it is a very important issue. This may help to minimize water consumption, reduce losses of irrigation water, and increase cultivated area.

In this regard, several investigators reported that values of WUE were. affected by two components, i.e., marketable yield and water applied (Saleh and El-Tantawy, 2001). On the other hand, Byan (2014) on snap bean showed that there were no differences between $80 \%$ ET and $100 \%$ ET for most growth parameters. In addition, $80 \%$ of ET increased the pod yield and improved the pod parameters, chemical composition, total chlorophyll, $\mathrm{Ca}, \mathrm{Mg}$, and protein. Therefore, this irrigation treatment can increase green bean productivity and improve pod quality. Moreover, Reducing water application from 100 to $60 \%$ of ET progressively increased WUE. Moreover, Faloye et al. (2016) on cowpea and Saleh et al. (2018) on snap bean showed that, the optimum growth, yield, water use efficiency and field water use efficiency for effective water management were obtained at irrigation regime of $60 \%$ ET which implies that about $40 \%$ of the irrigation can be saved.

Recent studies have focused on the use of plant extracts to improve vegetative growth and increase the production of many plants, because these extracts contain some important nutrients and growth regulators, vitamins and organic acids, which vary in quantity and quality in different parts of the plant as well as easy to be absorbed by the plant and cheaply priced (Abed Al-Hussain and Ibriham, 2009). Date palm (Phoenix dactylifera L. family Palmaceae) pollen grains consider one of the most effective and commonly used in the Middle East, especially in Egypt, where there are four famous local dates in Egypt; Amhat, Hiani, Sewy and Zaghlol. Date palm pollen grains extract has many compounds which are important in biological processes such as enzymes electrophoresis, sterols, triterpenes, saponins, proteins, vitamins $\mathrm{A}, \mathrm{C}$ and $\mathrm{E}$, minerals such as $\mathrm{B}, \mathrm{Zn}, \mathrm{Se}, \mathrm{Fe}, \mathrm{Mo}, \mathrm{Cu}, \mathrm{Mn}$, Carbohydrates, glycosides and amino acids (Hassan, 2011; Basuny et al., 2013) which help in improving plants growth. Moreover, Abo Al-Mikh (2017) and Abdulkadhim (2019), found that the spray of the palm pollen grains extract improved vegetative qualities of plant height, leaf area, number of leaves and dry weight of vegetative and root group, as well as the proportion of NPK for pomegranate seedlings.

Moreover, it was found that, application of bio stimulants, i.e. amino acids extract was found to extent positive effect of plant growth which overcomes the harmful effect of some environmental stress such as drought. Amino acids have traditionally been considered as precursors and constituents of proteins, and play an important role in plant metabolism as well as development. Many studies reported that the foliar application of amino acids caused an enhancement in plant growth, fruit yield and its components (El-Shabasi et al., 2005 on cucumber; Neeraja et al., 2005 on tomato; Awad et al., 2007 on garlic; Hayat et al. 2012).

In addition, several investigators found that, Nano-fertilizers are used recently as an alternative to conventional fertilizers for slow release and efficient use by plants. Nanofertilizers could enhance nutrient use efficiency and decrease the costs of environmental protection, (Naderi and Shahraki, 2013). One example of that lithovit, it is a natural intensified 
$\mathrm{CO}_{2}$ foliar fertilizer for indoor/outdoor use it, is a top-quality natural technological product created by tribodynamic activation and micronization to levels of 10-20 microns. lithovit can considerably increase the photosynthesis rate, since one of the essential factors limiting photosynthesis outdoors is the lower natural $\mathrm{CO}_{2}$ content of the air, this leads to yield increases (up to $50 \%$ and more), accompanied by a reduced water requirement (by up to $75 \%$ ), and since with using lithovit, plants are able to keep the stomata closed longer time in case of water stress (balancing of nutrients). In addition, the micro-nutrients also contained in the product and the trace elements that influence plant physiology and increase the resistance against unfavorable weather condition and diseases, growth, vitality and general quality of the crop. The additional supply of micronutrients from the lithovit complex provides a source of key plant available elements required to aid photosynthetic activity, (Thorn and Rogan, 2015). Moreover, Abd ElAal and Rania ( 2018) reported that foliar application with growth stimulators as lithovit at $500 \mathrm{mg} / \mathrm{l}$ and amino acids at $4 \mathrm{ml} / 1$ induced favorable results on soybean cultivation which improved its growth, productivity and quality.

The objective of this experiment was to study the influence of foliar spraying with aqueous extract of date palm pollen grains as a natural bio- stimulant on common bean plants to improve the vegetative growth, yield and its chemical composition as well as water use efficiency under different irrigation levels.

\section{MATERIALS AND METHODS}

The present work was carried out during two successive seasons of 2017 and 2018 at the Experimental Farm, Kaha Station, Qalubia Governorate to study the effect of different irrigation levels and foliar spray with some safety materials (date palm pollen grains extract and lithovit) on growth, seed yield and seed quality as well as water use efficiency of common bean plants grown in clay soil using drip irrigation system. Soil of the experiment was clay in texture with $7.2 \mathrm{pH}, 3.5 \mathrm{EC} 1.15 \%$ organic matters, $115 \mathrm{ppm} \mathrm{N}, 41 \mathrm{ppm} \mathrm{P}$ and 99 ppm K. Seeds of common bean cv. Nebraska were obtained from Hort. Res. Inst., Agric. Res.
Center, Egypt and sown on February $23^{\text {rd }}$ and $22^{\text {nd }}$ in 2017 and 2018 seasons, respectively. Seeds were sown in hills on one side of ridge (two dripper lines) at $35 \mathrm{~cm}$ spaces between the hills. The area of each experimental plot was $2.8 \mathrm{~m}^{2}$ (4 $\mathrm{m}$ long with $0.7 \mathrm{~m}$ width).

The experiment was arranged in a split plot design with three replicates. It was included fifteen treatments, i.e., the combination between 3 irrigation levels, namely $50 \%, 75 \%$ and $100 \%$ from crop evapotraspiration (ETc) which calculated according to historical class A pan evaporation data (2016 and 2017) for Qalubia region, expressed as $\mathrm{mm} /$ day were distributed at random in main plots and five safety materials were used, i.e. (water, date palm pollen grains extract at 1,3 and $5 \mathrm{~g} / \mathrm{L}$ and lithovit at $\mathrm{g} / \mathrm{L}$ ) occupied in the sub plots. Irrigation water quantities (as average of two seasons) were about $484.36 \mathrm{~m}^{3} / \mathrm{fad}$., for $50 \%$ ETc, 726.54 $\mathrm{m}^{3} /$ fad., for $75 \%$ ETc and $968.72 \mathrm{~m}^{3} /$ fad., for $100 \%$ ETc. Initial irrigation treatments was at 19 days up to 109 days from sowing. Plants were sprayed three times with aqueous solution of the used materials; the first spray was conducted at the three true leaves stage, whereas the second and third sprays were preformed later every 12 days intervals.

The other cultural practices for growing common bean plants were carried out as recommended by Egyptian Ministry of Agriculture.

\section{Preparation of Date Palm Pollen Grains Extracts}

Pollen grains of Egyptian date palm (Phoenix dactylifera L.) were collected at the end of March from Shabramant, Giza, Egypt during the agricultural season at the beginning of the opening the covers of the male species. The extract was prepared from pollen grains of date palm using the procedure reported by Nagai $\boldsymbol{e t}$ al. (2002) with some modifications as follows: To prepare three concentrations of water pollen grains extract (1,3 and $5 \mathrm{~g})$ of pollen grains whereas every one soaked in 1 litter of distilled water for 24 hours and turning with electric mixer and filter the extract with filter paper.

Components of date palm pollen grains taken as shown in Table 1 .

Names and contains of the safety materials as shown in Table 2. 
Table 1. Components of date palm pollen grains according to Hassan (2011)

\begin{tabular}{|c|c|}
\hline Subject & Ingredient \\
\hline Moisture & $28.80(\%)$ \\
\hline Vitamins & $\begin{array}{c}\text { Vitamin A, H, E, D, K and group vitamins B (B1, B2, B6, B12, Niyasine, Butine, } \\
\text { Anysitole, Rothine }\end{array}$ \\
\hline Hormones & Astron hormone \\
\hline Food Ingredients & Carbohydrates $13 \%$, Protein $35 \%$, Fat $5 \%$ \\
\hline Mineral salts & Ti, Mo, B, Si, Zn, I, Cu, Mn, Mg, Fe, Cl, Na, S , P, K, Ca \\
\hline Amino acids & $\begin{array}{c}\text { Alanine (Ala) 2.61 Arginine (Arg) 1.61 Aspartic acid (Asp) } 3.55 \text { Glutamic acid } \\
\text { (Glu) 1.74 Glycine (Gly) 2.24 Serine (Ser) } 1.89 \text { Cysteine (Cys) } 0.42 \text { Tyrosine } \\
\text { (Tyr) 1.55 Proline (Pro) } 0.28 \text { Ammonia } 0.45\end{array}$ \\
\hline Other compounds & $\begin{array}{l}\text { phenolic acids, , clycerides, mono acids, bilateral acids and triple acids } \\
\text { auxin (IBA) and tryptophan (auxin precursor) }\end{array}$ \\
\hline
\end{tabular}

Table 2. Names and contains of the safety materials used in this study

\begin{tabular}{lcc}
\hline Compound name & Composition & Concentration \\
\hline Control & Tap water & - \\
Date palm pollen grains & As shown in Table 1 & $1-3-5 \mathrm{~g} /$ liter \\
Lithovit & $80.2 \% \mathrm{Ca} \mathrm{Co}_{3}, 4.6 \% \mathrm{Mg} \mathrm{Co}_{3}, 0.2 \% \mathrm{~K}_{2} \mathrm{O}, 0.75 \% \mathrm{Fe}$ & $1 \mathrm{~g} /$ liter \\
\hline
\end{tabular}

\section{Water Management Measurements}

The water requirement for common bean plants was calculated based on the following formulas, according to Allen et al. (1998).

(1) $\mathrm{ET}_{0}=\mathrm{Kp} \times$ Epan mm/day

Where:

$\mathrm{ET}_{0}=$ Potential evapotranspiration

$\mathrm{Kp}=$ Pan Coefficient $=0.85$

Epan $=$ Pan evaporation in $\mathrm{mm} /$ day

(2) $\mathrm{ETc}=\mathrm{ET}_{0} \times \mathrm{Kc} \mathrm{mm} /$ day

Where:

$\mathrm{ET}_{0}=$ the rate of evapotranspiration from an excessive surface of green cover of uniform height $(8$ to $15 \mathrm{~cm})$ actively growing, completely shading the ground and did not face shortage in water.

$$
\mathrm{Kc}=\text { Crop coefficient }
$$

ETcrop $=$ the water requirement of a given crop in $\mathrm{mm}$ per unit of time $\mathrm{mm} / \mathrm{day}, \mathrm{mm} / \mathrm{month}$ or $\mathrm{mm} /$ season.

Crop evapotranspiration and total water consumption of common bean plants during seasons of 2017 and 2018 are presented in Table 3.

\section{Water Use Efficiency (WUE)}

Water use efficiency was calculated for different treatments using the following equation (Monteith, 1986).

WUE $=$ Total seed yield $(\mathrm{kg} / \mathrm{fad}$.$) / Total water$ consumption $\left(\mathrm{m}^{3} / \mathrm{fad}\right.$.)

The monthly temperature and relative humidity during growing seasons of 2017 and 2018 are presented in Table 4. 
Table 3. Crop evapotranspiration and total water consumption of common bean plant at different levels of irrigation during 2017 and 2018 seasons

\begin{tabular}{|c|c|c|c|c|c|c|c|c|c|c|}
\hline \multirow[b]{2}{*}{ Growth stage } & \multirow[t]{2}{*}{ Days } & \multirow[t]{2}{*}{$\begin{array}{c}\text { Class A } \\
\text { pan } \\
\text { mm }\end{array}$} & \multirow[t]{2}{*}{$\begin{array}{c}\text { Potential } \\
\text { evapotranspiration } \\
\left(E \mathbf{T}_{0}\right)\end{array}$} & \multirow[t]{2}{*}{$\begin{array}{c}\text { FAO } \\
\text { Kc }\end{array}$} & \multicolumn{3}{|c|}{$\begin{array}{c}\text { Crop } \\
\text { evapotranspiration } \\
\mathrm{mm}\end{array}$} & \multicolumn{3}{|c|}{$\begin{array}{c}\text { Total water } \\
\text { consumption } \\
\left(\mathrm{m}^{3} / \text { fad. }\right)\end{array}$} \\
\hline & & & & & $50 \%$ & $75 \%$ & $100 \%$ & $50 \%$ & $75 \%$ & $100 \%$ \\
\hline \multicolumn{11}{|c|}{ First season } \\
\hline Initial & $20(19-39)$ & 2.82 & 2.40 & 0.5 & 12.00 & 18.00 & 24.00 & 30.00 & 45.00 & 60.00 \\
\hline Crop development & $30(39-69)$ & 3.64 & 3.10 & 0.8 & 37.20 & 55.80 & 74.40 & 130.20 & 195.30 & 260.40 \\
\hline Mid- season & $30(69-99)$ & 4.35 & 3.70 & 1.1 & 61.05 & 91.57 & 122.10 & 244.20 & 366.30 & 488.40 \\
\hline Late season & $10(99-09)$ & 5.05 & 4.30 & 0.9 & 19.35 & 29.02 & 38.70 & 87.07 & 130.61 & 174.15 \\
\hline Seasonal & 90 & 3.96 & 3.37 & 0.8 & 129.60 & 194.40 & 259.20 & 491.47 & 737.21 & 982.95 \\
\hline \multicolumn{11}{|c|}{ Second season } \\
\hline Initial & $20(19-39)$ & 2.70 & 2.30 & 0.5 & 11.50 & 17.25 & 23.00 & 28.75 & 43.12 & 57.50 \\
\hline Crop development & $30(39-69)$ & 3.41 & 2.90 & 0.8 & 34.80 & 52.20 & 69.60 & 121.80 & 182.70 & 243.60 \\
\hline Mid- season & $30(69-99)$ & 4.23 & 3.60 & 1.1 & 59.40 & 89.10 & 118.8 & 237.60 & 356.40 & 475.20 \\
\hline Late season & $10(99-09)$ & 5.17 & 4.40 & 0.9 & 19.80 & 29.70 & 39.60 & 89.10 & 133.65 & 178.20 \\
\hline Seasonal & 90 & 3.87 & 3.30 & 0.8 & 125.50 & 188.25 & 251.00 & 477.25 & 715.87 & 954.50 \\
\hline
\end{tabular}

Table 4. The monthly temperature $\left({ }^{\circ} \mathrm{C}\right)$ and relative humidity (\%) during 2017 and 2018 seasons

\begin{tabular}{lcccccc}
\hline Month & \multicolumn{3}{c}{$\mathbf{2 0 1 7}$} & \multicolumn{3}{c}{$\mathbf{2 0 1 8}$} \\
\cline { 2 - 7 } & \multicolumn{2}{c}{ Temperature $\left({ }^{\circ} \mathbf{C}\right)$} & RH (\%) & \multicolumn{2}{c}{ Temperature $\left({ }^{\circ} \mathbf{C}\right)$} & RH (\%) \\
& Max. & Min. & & Max. & Min. & \\
\hline March & 38.2 & 9.3 & 100 & 32.8 & 12.5 & 93 \\
April & 38.8 & 12.6 & 100 & 40.1 & 16 & 100 \\
May & 45.4 & 16.8 & 92.3 & 42.0 & 19.1 & 89.9 \\
June & 43.6 & 20.4 & 87.1 & 41.9 & 23.3 & 92.3 \\
\hline
\end{tabular}

\section{Central Lab. for Agricultural Climate}

\section{Sampling and collecting data}

\section{Vegetative growth characteristics}

Three plants from each experiment unit were randomly taken at flowering stage ( 55 days after sowing) to measure plant growth characteristics i.e., plant length (the length of main stem, $\mathrm{cm}$ ), stem diameter $(\mathrm{cm})$, No. of leaves/plant, No. of branches/plant and dry weights of shoots (Leaves and stems)/ plant. The samples of the vegetative parts were dried in the oven at $75^{\circ} \mathrm{C}$ till constant weight and then the dry weight per plant was calculated using the standard methods as illustrated by AOAC (1990).

The leaf area was calculated at flowering stage (55 days after sowing) from the fourth upper leaves according to the following formula of Wallace and Munger (1965):

Leaf area $\left(\mathrm{cm}^{2}\right)=$ Leaves dry weight $(\mathrm{g}) \mathrm{x}$ disk area/disk dry weight $(\mathrm{g})$ 


\section{Yield and its components}

At harvest, (120 days after sowing) samples of dry seed yield were taken from each experiment unit to estimate yield characters, i.e., number of dry pods/plant, number of dry seeds/ pod, weight of 1000 dry seeds (g), dry seed yield ton/fad.

\section{Chemical properties}

Total leaf chlorophyll was measured at flowering stage (55days after sowing) from the fourth upper leaves using Minolta chlorophyll Meter SPAD- 501 as SPAD units

Total nitrogen, phosphorus and potassium were determined in the dry seeds on the basis of dry weight according to the methods described by Bremner and Mulvaney (1982), Olsen and Sommers (1982) and Jackson (1967), respectively.

\section{Total protein (\%)}

It was determined as nitrogen of seed content and converted to its equivalent protein content by multiplying total nitrogen x 6.25 (AOAC, 1990)

\section{Statistical Analysis}

All data were subjected to statistical analysis according to the procedures reported by Snedecor and Cochran (1980) using M. stat program and means were compared by LSD multiple range tests at the $5 \%$ level of probability in the two seasons of experimentation.

\section{RESULTS AND DISCUSSION}

\section{Vegetative Growth Characteristics}

\section{Effect of irrigation levels}

The vegetative growth parameters of common bean plants, i.e., plant length, number of leaves/plant, stem diameter, number of branches/plant, leaf area as well as dry weight of plant as affected by irrigation levels are shown in Table 5. The results revealed that irrigation regime did not exert significant effect on stem diameter or number of branches/plant in both growing season in spite of the $100 \%$ and $75 \%$ of crop evapotraspiration (ETc) showed obvious increment in plant length, number of leaves, leaf area as well as dry weight of plant compared to $50 \%$ of ETc. The abundance of water under $100 \%$ and 75 of ETc encouraged the meristematic activity and hence the length of plants. The greatest number of leaves was found on the tallest plants where the abundance of water under $100 \%$ and $75 \%$ of ETc promoted the meristematic activity then led to increasing the length of the plant and hence, number of leaves. Moreover, the highest values of leaf area founded under the levels of $100 \%$ or $75 \%$ of ETc might enable to plants intercept and synthesize more metabolites than plants irrigated by $50 \%$ treatment which might be reflected on the fresh and dry weight of the plants. These results are in the same line with those obtained by Byan (2014) and Saleh et al. (2018) on snap bean.

\section{Effect of foliar spray by date palm pollen grains extract and lithovit}

The recorded results in Table 5 illustrate that foliar application by date palm pollen grains extract at 5,3 or $1 \mathrm{~g} / \mathrm{L}$ respectively, followed by foliar application by lithovit $1 \mathrm{~g} / \mathrm{L}$ caused stimulatory effects on all vegetative growth parameters compared with the control treatment in both seasons, this may be due to the fact that date palm pollen grains extract contains many mineral elements, including $\mathrm{K}, \mathrm{Ca}, \mathrm{Mg}, \mathrm{P}$, in addition to proteins, vitamins and organic acids as shown in Table 1, which increase the process of photosynthesis, respiration and metabolism thus encouraging cell division and elongation, in addition to the presence of micro elements $\mathrm{Fe}$, $\mathrm{Mn}, \mathrm{Zn}$, the $\mathrm{Zn}$ component which plays an important role in activating many of the enzymes necessary to formation the auxins that cause cell division and elongation, thus increasing plant height, stem diameter, leaves number and its area (Hassan, 2011; Basuny et al., 2013) came to the same results. Concerning to lithovit, it is a natural intensified $\mathrm{CO}_{2}$ foliar fertilizer can considerably increase the photosynthesis rate. In addition, the micronutrients also contained in the product and the trace elements that influence plant physiological process and increase growth (Thorn and Rogan, 2015; Abd El-Aal and Rania, 2018). 
Table 5. Effect of irrigation levels and foliar spray with date palm pollen grain extract and lithovit on vegetative growth of common bean plants during 2017 and 2018 seasons.

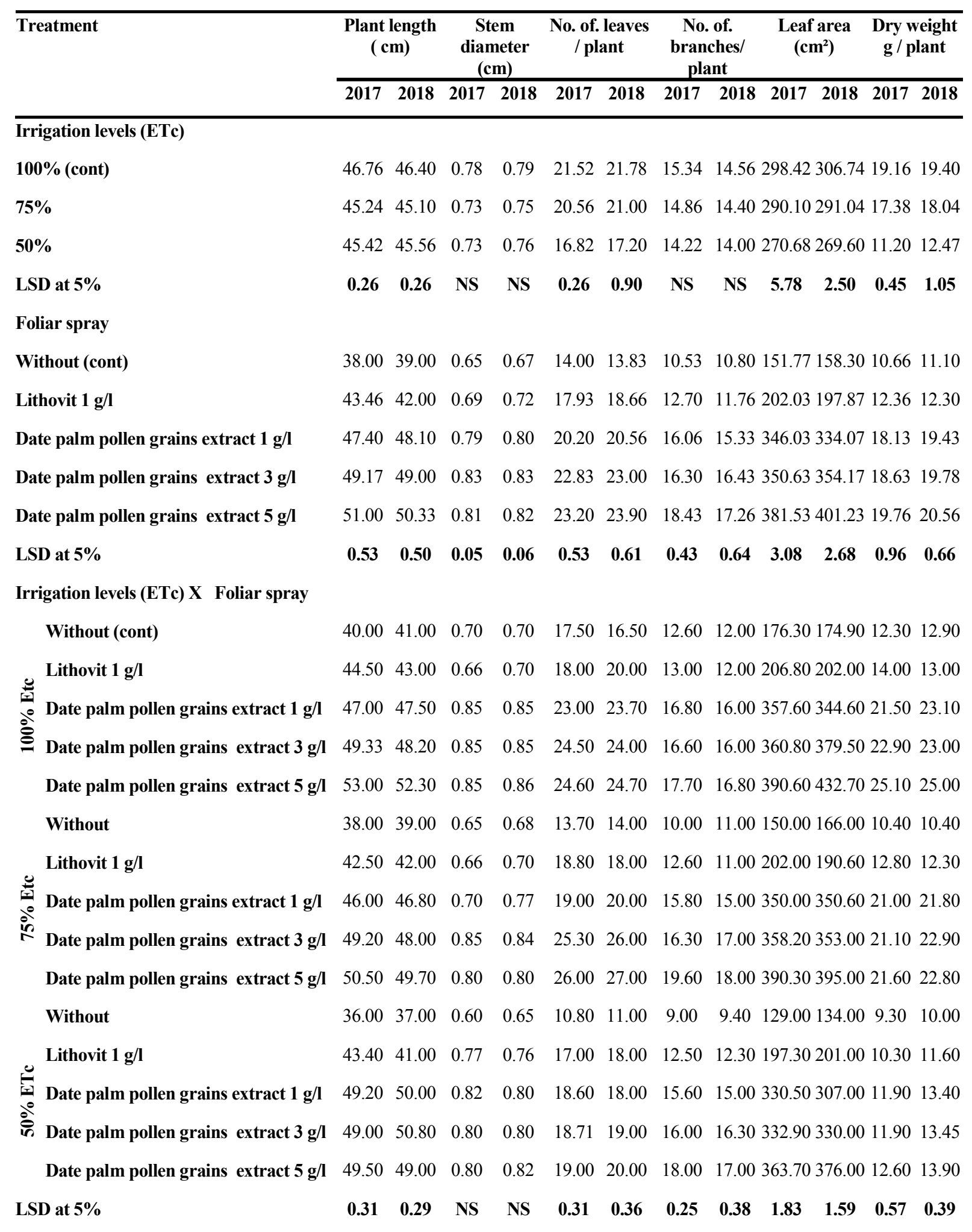

Irrigation water quantity (as average of two seasons) were about $484.36 \mathrm{~m}^{3}$ water/fad., for $50 \%$ Etc, $726.54 \mathrm{~m}^{3} \mathrm{water} / \mathrm{fad}$., for $75 \%$ Etc and $968.72 \mathrm{~m}^{3}$ water/fad., for $100 \%$ Etc. 
Effect of the interaction between irrigation levels and foliar spray with date palm pollen grains extract and lithovit

The results of the interaction effect between irrigation levels and safety materials on vegetative growth, i.e., plant length, number of leaves, number of branches, stem diameter and leaf area as well as dry weight of common bean plant are shown in Table 5. The recorded results illustrate that the plants sprayed by date palm pollen grains extract at $5 \mathrm{~g} / \mathrm{l}$ and irrigated by $100 \%$ or $75 \%$ of irrigation water gave the highest values of all vegetative growth parameters except stem diameter which showed non-significant differences between irrigation water quantity and safety materials in both growing seasons. The enhancing effect of the interaction treatments may be due to the fact that date palm pollen grains extract contains several compounds from vitamins, micro elements and hormones as well as amino acids which it having traditionally been considered as precursors to and constituents of proteins, which plays an important role in plant metabolism and development. Many investigators reported that the foliar application of amino acids caused an enhancement in plant growth (El-Shabasi et al., 2005 on cucumber; Neeraja et al., 2005 on tomato; Awad et al., 2007 on garlic; Hayat et al., 2012).

\section{Yield and Its Components}

\section{Effect of irrigation levels}

Results in Table 6 obviously indicate the effect of different water regime levels on yield and its components of common bean. In this respect, the results reveal that, the means of pod number/plant, weight of 1000 dry seeds and seed yield were the highest in irrigation regime at $100 \%$ ETc followed by $75 \%$ ETc and the lowest was obtained in irrigation regime of 50\% ETc in both growing seasons. Moreover, the results revealed that irrigation regime did not exert significant effect on number of seeds/pod in both growing season, this stimulation of seed yield production is considered as a direct result of the vigorous growth (Table 5). These results are in agreement with those of Byan (2014) on snap bean, Faloye et al. (2016) on cowpea and Saleh et al. (2018) on snap bean.
Effect of foliar spray with date palm pollen grains extract and lithovit

Results in Table 6 reveal that foliar spraying common bean plants by date palm pollen grains extract at 5, 3 or $1 \mathrm{~g} / \mathrm{L}$ respectively, then lithovit $1 \mathrm{~g} / \mathrm{L}$ induced significant increases on all yield and its components i.e., number of pods/plant, number of dry seeds/pod, weight of 100 dry seeds and seed yield ton/fad., compared with the control treatment in both growing seasons. This may be due to the fact that date palm pollen grains extract contains many mineral elements, including $\mathrm{K}, \mathrm{Ca}, \mathrm{Mg}, \mathrm{P}$, in addition to proteins, vitamins and organic acids as shown in Table 1. In other words, date palm pollen grains extract and lithovit as foliar applications increased number of dry seeds/pod as well as causing significant increment on the dry seed weight and this reflect on the total dry seed yield, this results are in harmony with those reported by Hassan (2011) on tomato and Basuny et al. (2013). Moreover, Abd El-Aal and Rania (2018) on soybean reported that foliar application with growth stimulators as lithovit at $500 \mathrm{mg} / \mathrm{l}$ improving its growth, productivity and quality.

Effect of the interaction between irrigation levels and foliar spray by date palm pollen grains extract and lithovit

The recorded results in Table 6 illustrate that the plants which sprayed with date palm pollen grains extract at 1,3 or $5 \mathrm{~g} / 1$ followed by lithovit at $1 \mathrm{~g} / 1$ and irrigated by $100 \%$ or $75 \%$ of irrigation water gave the highest values of the total seed yield and its components i.e., number of pods/plant, weight of 1000 seeds and dry seed yield ton/fad., compared to the control, i.e. water foliar spray treatment in both growing seasons. Moreover, the results revealed that, the interaction between irrigation levels and foliar spray by date palm pollen grains extract and lithovit did not exert significant effect on number of seeds/pod in both growing season. This may be due to the fact that date palm pollen grains extract contains amino acids which play an important role in plant metabolism and development. Many studies reported that the foliar application of amino acids caused an enhancement in fruit yield and its components (El-Shabasi et al., 2005 on cucumber; Neeraja $\boldsymbol{e t}$ al., 2005 on tomato; Awad et al., 2007 on garlic; Hayat et al., 2012). 
Table 6. Effect of irrigation levels and foliar spray with date palm pollen grain extract and lithovit on dry seed yield and its components of common bean plants during 2017 and 2018 seasons

\begin{tabular}{|c|c|c|c|c|c|c|c|c|c|}
\hline \multirow{2}{*}{\multicolumn{2}{|c|}{ Treatment }} & \multicolumn{2}{|c|}{$\begin{array}{c}\text { No.of } \\
\text { pods/plant }\end{array}$} & \multicolumn{2}{|c|}{$\begin{array}{c}\text { No.of } \\
\text { seeds/pod }\end{array}$} & \multicolumn{2}{|c|}{$\begin{array}{c}\text { Weight of } 1000 \\
\text { dry seeds (g) }\end{array}$} & \multicolumn{2}{|c|}{$\begin{array}{l}\text { Total seed yield } \\
\text { ton/fad. }\end{array}$} \\
\hline & & 2017 & 2018 & 2017 & 2018 & 2017 & 2018 & 2017 & 2018 \\
\hline \multicolumn{10}{|c|}{ Irrigation levels (ETc) } \\
\hline \multicolumn{2}{|c|}{$100 \%$ (cont) } & 21.87 & 21.58 & 4.30 & 4.25 & 418.92 & 425.60 & 1.58 & 1.56 \\
\hline \multicolumn{2}{|c|}{$75 \%$} & 21.86 & 22.16 & 4.16 & 4.20 & 415.88 & 414.60 & 1.45 & 1.50 \\
\hline \multicolumn{2}{|c|}{$50 \%$} & 21.21 & 21.23 & 4.14 & 4.25 & 401.00 & 401.52 & 1.29 & 1.40 \\
\hline \multicolumn{2}{|c|}{ LSD at $5 \%$} & 0.52 & 0.52 & NS & NS & 1.36 & 0.84 & 0.02 & 0.03 \\
\hline \multicolumn{10}{|c|}{ Foliar spray } \\
\hline \multicolumn{2}{|c|}{ Without (cont) } & 18.18 & 17.93 & 3.13 & 3.40 & 280.17 & 293.83 & 0.59 & 0.67 \\
\hline \multicolumn{2}{|c|}{ Lithovit 1 g/l } & 20.76 & 20.94 & 4.16 & 4.06 & 362.67 & 362.93 & 1.02 & 1.06 \\
\hline \multicolumn{2}{|c|}{ Date palm pollen grains extract $1 \mathrm{~g} / \mathrm{l}$} & 22.72 & 22.46 & 4.36 & 4.49 & 455.97 & 452.17 & 1.61 & 1.77 \\
\hline \multicolumn{2}{|c|}{ Date palm pollen grains extract $3 \mathrm{~g} / \mathrm{l}$} & 23.04 & 23.16 & 4.60 & 4.49 & 483.37 & 480.83 & 1.91 & 1.92 \\
\hline \multicolumn{2}{|c|}{ Date palm pollen grains extract $5 \mathrm{~g} / \mathrm{l}$} & 23.53 & 23.80 & 4.73 & 4.72 & 477.50 & 479.77 & 2.07 & 2.01 \\
\hline \multicolumn{2}{|c|}{ LSD at $5 \%$} & 0.61 & 0.58 & 0.30 & 0.64 & 0.56 & 0.51 & 0.03 & 0.05 \\
\hline \multicolumn{10}{|c|}{ Irrigation levels (ETc) X Foliar spray } \\
\hline \multirow{5}{*}{ 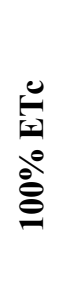 } & Without (cont) & 19.50 & 18.80 & 3.40 & 3.52 & 257.50 & 305.20 & 0.64 & 0.75 \\
\hline & Lithovit 1 g/l & 20.10 & 19.33 & 4.30 & 4.00 & 395.00 & 397.00 & 1.28 & 1.16 \\
\hline & Date palm pollen grains extract $1 \mathrm{~g} / \mathrm{l}$ & 22.66 & 22.50 & 4.20 & 4.40 & 453.50 & 508.30 & 1.65 & 1.79 \\
\hline & Date palm pollen grains extract $3 \mathrm{~g} / \mathrm{l}$ & 23.50 & 23.40 & 4.80 & 4.60 & 518.10 & 474.10 & 2.16 & 2.05 \\
\hline & Date palm pollen grains extract $5 \mathrm{~g} / \mathrm{l}$ & 23.60 & 23.90 & 4.80 & 4.75 & 470.50 & 443.40 & 2.21 & 2.06 \\
\hline \multirow{5}{*}{$\begin{array}{l}\underset{G}{0} \\
\stackrel{0}{0} \\
\stackrel{0}{r}\end{array}$} & Without & 18.61 & 18.33 & 3.00 & 3.20 & 299.00 & 300.50 & 0.60 & 0.67 \\
\hline & Lithovit 1 g/l & 20.50 & 22.00 & 4.00 & 4.00 & 357.00 & 354.50 & 1.09 & 1.09 \\
\hline & Date palm pollen grains extract $1 \mathrm{~g} / \mathrm{l}$ & 23.20 & 23.20 & 4.50 & 4.60 & 474.40 & 469.00 & 1.67 & 1.88 \\
\hline & Date palm pollen grains extract $3 \mathrm{~g} / \mathrm{l}$ & 23.43 & 23.43 & 4.50 & 4.40 & 467.00 & 484.00 & 1.83 & 1.89 \\
\hline & Date palm pollen grains extract $5 \mathrm{~g} / \mathrm{l}$ & 23.56 & 23.85 & 4.80 & 4.80 & 482.00 & 465.00 & 2.06 & 2.00 \\
\hline \multirow{5}{*}{$\begin{array}{l}0 \\
\stackrel{0}{0} \\
\stackrel{0}{\circ} \\
\stackrel{0}{\circ}\end{array}$} & Without & 16.43 & 16.66 & 3.00 & 3.50 & 284.00 & 275.80 & 0.53 & 0.61 \\
\hline & Lithovit $1 \mathrm{~g} / \mathrm{l}$ & 21.70 & 21.50 & 4.20 & 4.18 & 336.00 & 337.30 & 0.71 & 0.93 \\
\hline & Date palm pollen grains extract $1 \mathrm{~g} / \mathrm{l}$ & 22.30 & 21.70 & 4.40 & 4.48 & 440.00 & 448.10 & 1.52 & 1.64 \\
\hline & Date palm pollen grains extract $3 \mathrm{~g} / \mathrm{l}$ & 22.21 & 22.66 & 4.50 & 4.48 & 465.00 & 465.20 & 1.74 & 1.84 \\
\hline & Date palm pollen grains extract $5 \mathrm{~g} / \mathrm{l}$ & 23.43 & 23.66 & 4.60 & 4.62 & 480.00 & 481.20 & 1.96 & 1.99 \\
\hline \multicolumn{2}{|c|}{ LSD at $5 \%$} & 0.36 & 0.34 & NS & NS & 0.33 & 0.31 & 0.01 & 0.02 \\
\hline
\end{tabular}

Irrigation water quantity (as average of two seasons) were about $484.36 \mathrm{~m}^{3} \mathrm{water} /$ fad., for $50 \%$ Etc, $726.54 \mathrm{~m}^{3} \mathrm{water} / \mathrm{fad}$., for $75 \%$ Etc and $968.72 \mathrm{~m}^{3}$ water/fad., for $100 \%$ Etc. 


\section{Chemical Properties}

\section{Effect of irrigation levels}

Results in Table 7 show the influence of irrigation levels on chemical properties of common bean seeds, i.e., protein percentage, $\mathrm{P} \%, \mathrm{~K} \%$ as well as total chlorophyll of the leaves. It was found that the plants irrigated by $100 \%$ of the calculated amount of water treatments, showed higher concentration of $\mathrm{P} \%$ in its seeds than those irrigated by other irrigation treatments. While, the plants irrigated by $75 \%$ of the calculated amount of water treatments produced seeds containing the highest value for each of $\mathrm{K} \%$, protein percentage and total chlorophyll in the leaves. These results may be due to abundance of water quantities encouraged the absorption of minerals and its translocation to leaves. These results are in agreement with those obtained by Byan (2014) on snap bean, Faloye et al. (2016) on cowpea and Saleh et al. (2018) on snap bean. Generally, drought reduces both nutrient uptakes by the roots and transport from the roots to the shoots, because of restricted transpiration rates and impaired active transport and membrane permeability.

\section{Effect of foliar spray with date palm pollen grains extract and lithovit}

The recorded results in Table 7 illustrate that the plants sprayed by date palm pollen grains extract or lithovit gave dry seeds contains the highest value for each of protein percentage in the dry seeds, $\mathrm{P} \%$ as well as total chlorophyll in the leaves while results revealed that foliar spray by date palm pollen grains extract and lithovit did not exert significant effect on $\mathrm{k} \%$ in the dry seeds during both growing seasons. This results may be due to the fact that date palm pollen grains extract contains many mineral elements, including $\mathrm{K}, \mathrm{Ca}, \mathrm{Mg}, \mathrm{P}$, in addition to proteins, vitamins and organic acids as shown in Table 1, Moreover, Abo Al-Mikh (2017) and Abdulkadhim (2019), found that the spray of the palm pollen grains extract improved proportion of NPK for pomegranate seedlings.

\section{Effect of the interaction between irrigation levels and foliar spray with date palm pollen grains extract and lithovit}

The recorded results in Table 7 illustrate that the plants sprayed by date palm pollen grains extract at $5 \mathrm{~g} / 1$ and irrigated by $75 \%$ of irrigation water gave the highest value for each of protein percentage, $\mathrm{P} \%$ as well as $\mathrm{k} \%$ in spite it did not reach to significance level in the case of $\mathrm{k} \%$ compared with the control (without) in both growing seasons. Moreover, the results revealed that foliar spray by date palm pollen grains extract at $3 \mathrm{~g} / 1$ and irrigated by $75 \%$ of irrigation water gave the highest values of total chlorophyll in the leaves at the first season but did not reach to significance level in the second season as well as irrigated by $50 \%$ of irrigation water treatment in both growing seasons.

\section{Water Use Efficiency (WUE)}

Water use efficiency of common bean plants at different levels of irrigation and foliar spray by date palm pollen grains extract and lithovit is shown in Figs. 1 and 2. Results illustrated that water use efficiency decreased as the amount of irrigation water increased to $100 \%$ level of Etc and the highest values were obtained from $50 \%$ treatment followed by $75 \%$ of ETc. This was true in both growing seasons as shown in Fig. 1. The reduction in WUE by increasing the amount of irrigation might be due to the increasing in common bean water consumption use (WCU) as shown in Fig. 1. In this regard Byan (2014) on snap bean, Faloye et al. (2016) on cowpea and Saleh et al. (2018) on snap bean found that water use efficiency was decreased at the high level of irrigation levels.

Regarding water use efficiency (WUE) for common bean plants sprayed by the materials used in this study, results in Fig. 2 show that plants sprayed by date palm pollen grains extract at 5,3 or $1 \mathrm{~g} / 1$, respectively, followed by lithovit $1 \mathrm{~g} / \mathrm{l}$ elucidated the highest values of WUE in the first season as well as in the second season. The increasing in WUE might be due to the increasing in total seed yield of common bean plants which produced as result of the favorable role of the foliar spray treatments as shown in Table 6. In this regard, several investigators reported that values of WUE were affected by two components, i.e., marketable yield and water applied (Saleh and El-Tantawy, 2001).

As shown in Table 8 , results illustrate that, the plants sprayed by date palm pollen grains extract at 5,3 or $1 \mathrm{~g} / 1$, respectively, followed by lithovit $1 \mathrm{~g} / 1$ and irrigated by $50 \%$ or by $75 \%$ of 
Table 7. Effect of irrigation levels and foliar spray with date palm pollen grain extract and lithovit on chemicals properties of common bean seeds and leaf chlorophyll during 2017 and 2018 seasons

\begin{tabular}{|c|c|c|c|c|c|c|c|c|c|}
\hline \multirow{2}{*}{\multicolumn{2}{|c|}{ Treatment }} & \multicolumn{2}{|c|}{$\mathbf{P}(\%)$} & \multicolumn{2}{|c|}{ K (\%) } & \multicolumn{2}{|c|}{ Protein (\%) } & \multicolumn{2}{|c|}{$\begin{array}{l}\text { Leaf chlorophyll } \\
\text { SPAD unite }\end{array}$} \\
\hline & & 2017 & 2018 & 2017 & 2018 & 2017 & 2018 & 2017 & 2018 \\
\hline \multicolumn{10}{|c|}{ Irrigation levels (ETc) } \\
\hline \multicolumn{2}{|c|}{$100 \%$ (cont) } & 0.34 & 0.35 & 1.47 & 1.49 & 17.67 & 17.65 & 40.78 & 40.18 \\
\hline \multicolumn{2}{|c|}{$75 \%$} & 0.30 & 0.30 & 1.61 & 1.61 & 19.03 & 19.59 & 41.40 & 41.68 \\
\hline \multicolumn{2}{|c|}{$50 \%$} & 0.29 & 0.34 & 1.42 & 1.43 & 18.55 & 18.66 & 41.06 & 40.92 \\
\hline \multicolumn{2}{|c|}{ LSD at $5 \%$} & NS & NS & NS & NS & NS & NS & NS & NS \\
\hline \multicolumn{10}{|c|}{ Foliar spray } \\
\hline \multicolumn{2}{|c|}{ Without (cont) } & 0.25 & 0.26 & 1.25 & 1.25 & 16.53 & 17.33 & 36.06 & 36.26 \\
\hline \multicolumn{2}{|c|}{ Lithovit 1 g/l } & 0.29 & 0.27 & 1.50 & 1.48 & 16.60 & 17.07 & 41.76 & 41.20 \\
\hline \multicolumn{2}{|c|}{ Date palm pollen grains extract $1 \mathrm{~g} / \mathrm{l}$} & 0.29 & 0.33 & 1.55 & 1.55 & 18.98 & 19.57 & 42.83 & 42.63 \\
\hline \multicolumn{2}{|c|}{ Date palm pollen grains extract $3 \mathrm{~g} / \mathrm{l}$} & 0.34 & 0.35 & 1.54 & 1.59 & 19.23 & 19.62 & 43.00 & 43.20 \\
\hline \multicolumn{2}{|c|}{ Date palm pollen grains extract $5 \mathrm{~g} / \mathrm{l}$} & 0.38 & 0.43 & 1.64 & 1.68 & 20.75 & 19.59 & 41.73 & 41.33 \\
\hline \multicolumn{2}{|c|}{ LSD at $5 \%$} & 0.03 & 0.05 & NS & NS & 0.64 & 0.65 & 0.65 & 0.68 \\
\hline \multicolumn{10}{|c|}{ Irrigation levels ( ETc )X Foliar spray } \\
\hline \multirow{5}{*}{ 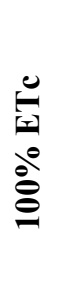 } & Without (cont) & 0.27 & 0.29 & 1.26 & 1.29 & 17.90 & 15.00 & 34.20 & 33.00 \\
\hline & Lithovit $1 \mathrm{~g} / \mathrm{l}$ & 0.26 & 0.24 & 1.36 & 1.33 & 17.96 & 15.20 & 42.60 & 41.00 \\
\hline & Date palm pollen grains extract $1 \mathrm{~g} / \mathbf{l}$ & 0.35 & 0.36 & 1.60 & 1.62 & 17.96 & 19.40 & 43.10 & 42.40 \\
\hline & Date palm pollen grains extract $3 \mathrm{~g} / \mathrm{l}$ & 0.41 & 0.41 & 1.65 & 1.65 & 16.58 & 20.70 & 42.70 & 42.90 \\
\hline & Date palm pollen grains extract $5 \mathrm{~g} / \mathrm{l}$ & 0.42 & 0.44 & 1.45 & 1.57 & 17.96 & 17.96 & 41.30 & 41.60 \\
\hline \multirow{5}{*}{$\begin{array}{l}\stackrel{0}{6} \\
\stackrel{0}{0} \\
i \frac{0}{2}\end{array}$} & Without & 0.23 & 0.22 & 1.22 & 1.24 & 15.24 & 19.30 & 39.00 & 39.80 \\
\hline & Lithovit $1 \mathrm{~g} / \mathbf{l}$ & 0.28 & 0.27 & 1.66 & 1.67 & 15.26 & 19.40 & 40.10 & 40.20 \\
\hline & Date palm pollen grains extract $1 \mathrm{~g} / \mathrm{l}$ & 0.28 & 0.27 & 1.72 & 1.69 & 19.58 & 19.90 & 42.80 & 43.00 \\
\hline & Date palm pollen grains extract $3 \mathrm{~g} / \mathrm{l}$ & 0.27 & 0.28 & 1.61 & 1.61 & 20.21 & 17.96 & 43.50 & 44.00 \\
\hline & Date palm pollen grains extract $5 \mathrm{~g} / \mathrm{l}$ & 0.45 & 0.46 & 1.82 & 1.85 & 24.88 & 21.40 & 41.60 & 41.40 \\
\hline \multirow{5}{*}{ 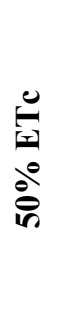 } & Without & 0.25 & 0.26 & 1.25 & 1.23 & 16.46 & 17.70 & 35.00 & 36.00 \\
\hline & Lithovit $1 \mathrm{~g} / \mathrm{l}$ & 0.33 & 0.31 & 1.49 & 1.44 & 16.58 & 16.60 & 42.60 & 42.40 \\
\hline & Date palm pollen grains extract $1 \mathrm{~g} / \mathrm{l}$ & 0.25 & 0.36 & 1.34 & 1.35 & 19.40 & 19.40 & 42.60 & 42.50 \\
\hline & Date palm pollen grains extract $3 \mathrm{~g} / \mathrm{l}$ & 0.35 & 0.37 & 1.37 & 1.52 & 20.91 & 20.21 & 42.80 & 42.70 \\
\hline & Date palm pollen grains extract $5 \mathrm{~g} / \mathrm{l}$ & 0.27 & 0.39 & 1.66 & 1.61 & 19.40 & 19.40 & 42.30 & 41.00 \\
\hline \multicolumn{2}{|c|}{ LSD at $5 \%$} & 0.02 & 0.03 & NS & NS & 0.38 & 0.38 & 0.36 & NS \\
\hline
\end{tabular}

Irrigation water quantity (as average of two seasons) were about $484.36 \mathrm{~m}^{3}$ water/fad., for $50 \%$ Etc, $726.54 \mathrm{~m}^{3} \mathrm{water} /$ fad., for $75 \%$ Etc and $968.72 \mathrm{~m}^{3}$ water/fad., for $100 \%$ Etc. 


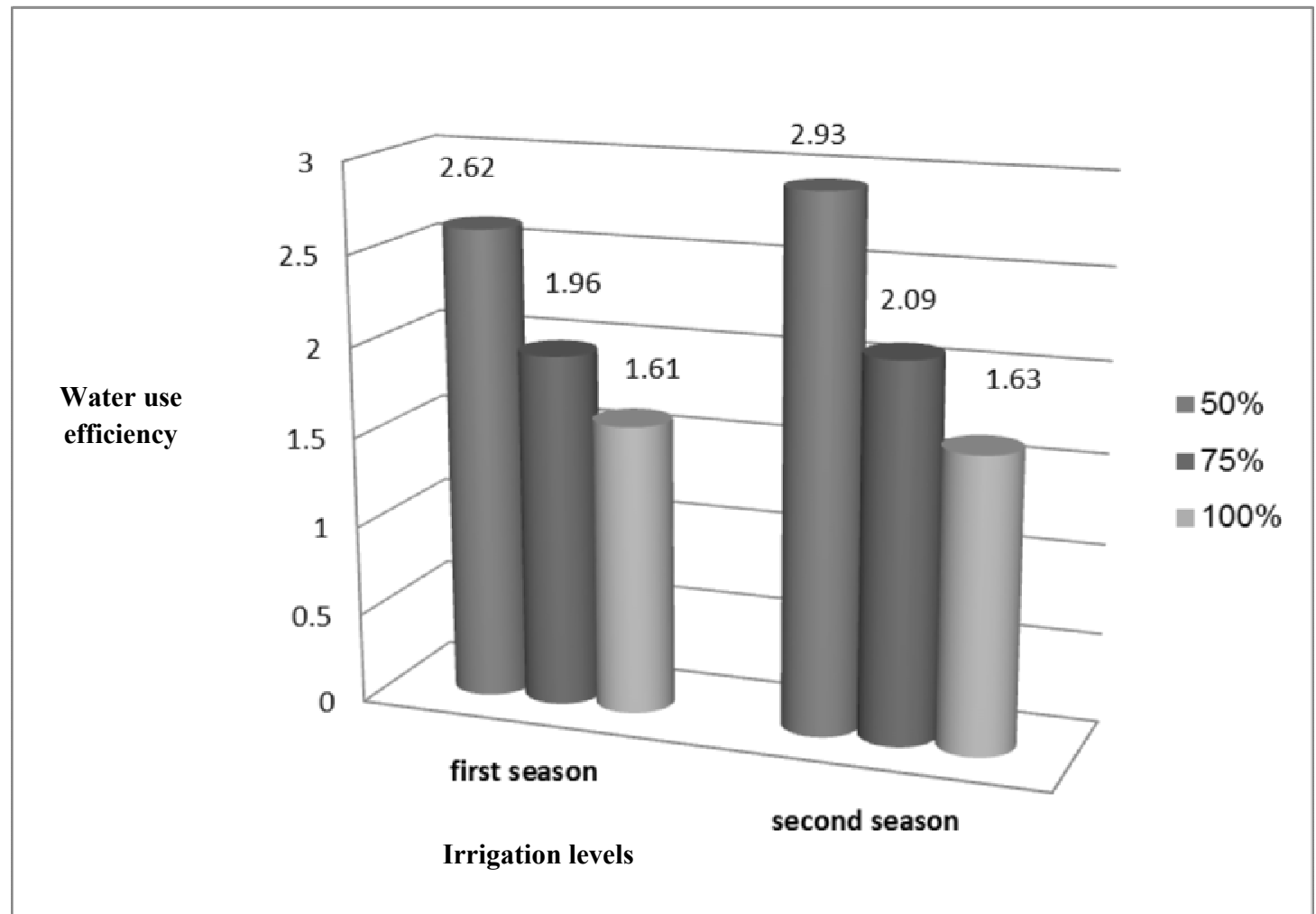

Fig. 1. Water use efficiency (WUE) of common bean plant at different levels of irrigation during 2017 and 2018 seasons

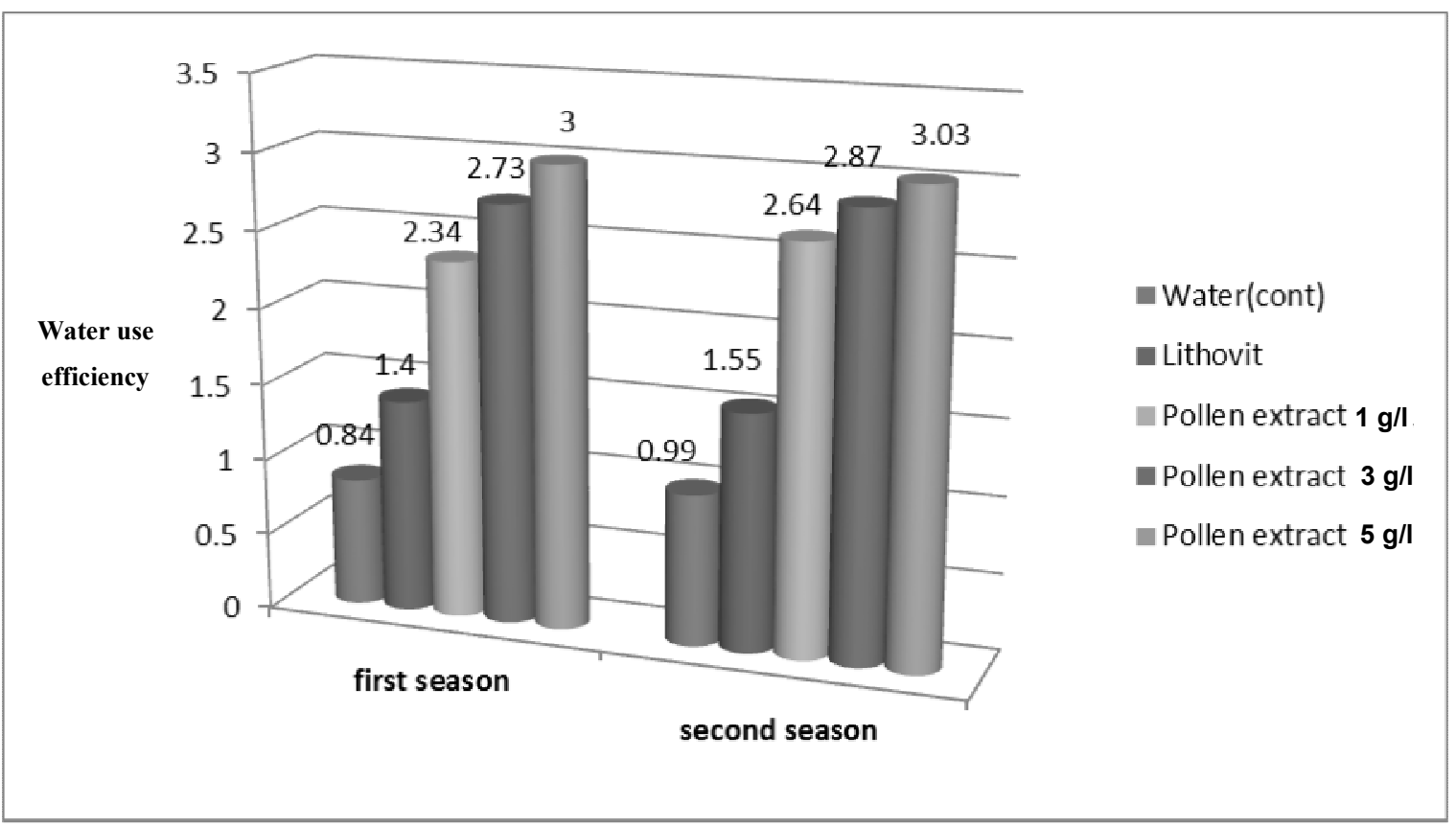

Fig. 2. Water use efficiency (WUE) of common bean plant at different foliar spray by date palm pollen grains extract and lithovit during 2017 and 2018 seasons 
Table 8. Effect of the interaction between irrigation levels and foliar spray with date palm pollen grains extract and lithovit on water use efficiency of common bean plants during 2017 and 2018 seasons

\begin{tabular}{lccccc}
\hline Foliar spray & $\begin{array}{c}\text { Tap water } \\
\text { (cont) }\end{array}$ & Lithovit1 g/l & $\begin{array}{c}\text { Date palm } \\
\text { pollen grains } \\
\text { extract 1 } \mathbf{~ g / l}\end{array}$ & $\begin{array}{c}\text { Date palm } \\
\text { pollen grains } \\
\text { extract 3 g/l }\end{array}$ & $\begin{array}{c}\text { Date palm } \\
\text { pollen grains } \\
\text { extract 5 g/l }\end{array}$ \\
\hline First season & & & & & \\
$\mathbf{1 0 0 \% ~ E T c ~}$ & 0.65 & 1.30 & 1.67 & 2.19 & 2.24 \\
$\mathbf{7 5 \%}$ ETc & 0.81 & 1.47 & 2.26 & 2.48 & 2.79 \\
$\mathbf{5 0 \%}$ ETc & 1.07 & 1.44 & 3.09 & 3.54 & 3.98 \\
Second season & & & & & \\
$\mathbf{1 0 0 \%}$ ETc & 0.78 & 1.21 & 1.87 & 2.14 & 2.15 \\
$\mathbf{7 5 \%}$ ETc & 0.93 & 1.52 & 2.62 & 2.64 & 2.79 \\
$\mathbf{5 0 \%}$ ETc & 1.27 & 1.94 & 3.43 & 3.85 & 4.16 \\
\hline
\end{tabular}

Etc gave the highest values of water use efficiency this was true in both growing seasons. The increasing in WUE might be due to the increasing in total seed yield of common bean plants which produced as result of the favorable role of the foliar spray treatments as shown in Table 6 and decreasing in common bean water consumption use.

\section{REFERENCES}

Abd El-Aal, M.M.M. and S.M. Rania (2018). Effect of foliar spray with lithovit and amino acids on growth, bio-constituents, anatomical and yield features of soybean plant. Plant Biotechnol., 187-201.

Abdulkadhim, J.S. (2019). Influence of biofertilizer and spraying with palm pollen grains extracts on some growth indicators and leaves content of nutrient in pomegranate cv. salimi. Plant Archives, 19 (1):1458-1464.

Abed Al-Hussain, R.M. and F.H. Ibriham, (2009). Effect of sparying whey and mineral nutrition in growth and yield per plant of tomato Lycopersicon esculentum Mill. J. Tikreet Univ. Agric. Res., 9 (2): 248-258.

Abo Al-Mikh, M.T. (2017). Influence of biofertilizer and spraying with the plant extracts on some growth indicators and leaves content of Nutrient in Punica granum (wonderful). Kufa J. Agric. Sci., 9 (3): 42-59.

Allen, R.G., L.S. Pereira, D. Raes and M.Smith (1998). Crop Evapotranspiration-Guidelines for Computing Crop Water RequirementsFAO Irrigation and Drainage Paper 56; FAO: Rome, Italy, 300.

AOAC (1990). Official Methods of Analysis of Association of Official Agricultural Chemists. $15^{\text {th }}, 1045-1106$.

Awad, E.M.M., A.M. Abd El-Hameed and Z.S. Shall (2007). Effect of glycine, lysine and nitrogen fertilizer rates on growth, yield and chemical composition of potato. J. Agric. Sci. Mansoura Univ., 32(10): 8541 - 8551.

Basuny, A.M., S.M. Arafat and H.M. Soliman (2013). Chemical analysis of olive and palm pollen grains. Antioxidant and antimicrobial activation properties. Wudpecker J. Food Technol., 1(2):14-21.

Bisbis, M.B., N. Gruda and M. Blanke (2018). Potential impacts of climate change on vegetable production and product quality-A review. J. Clean. Prod., 170: 1602-1620.

Bremner, J.M. and C.S. Mulvaney (1982). Total nitrogen. In: Pag, A.L., R.H. Miller and D. R. Keeny (Eds).Methods of soil analysis. Part 2, Ame. Soc. Agron. Madison, W.I. USA, 595-624. 
Byan, U.A.I. (2014). Influence of using some safety materials on water requirement and water use efficiency of snap bean plant. Arab Univ. J. Agric. Sci., Ain Shams Univ., Cairo, $22(2): 381-394$.

El-Shabasi, M.S., S.M. Mohamed and S.A. Mahfouz (2005). Effect of foliar spray with amino acids on growth, yield and chemical composition of garlic plants. $6^{\text {th }}$ Arabian Conf. Hort. Ismailia, Egypt.

Faloye, O.T., A.S. Ojo and O. Fasanu (2016). Effect of irrigation on growth of cowpea at different developmental stages and water use efficiency. Swift. J. Agric. Res., 2(1): 1-11.

Hassan, H.M.M. (2011). Chemical Composition and Nutritional Value of Palm Pollen grains Grain. Global J. Biotechnol. and Biochem., $6(1): 1-7$.

Hayat, S.Q., M.N. Alyemeni, A.S. Wani, J. Pichtel and A. Ahmad, (2012). Role of proline under changing environments. Plant Signal Behav., 7(11):1456-1466.

Jackson, M.L. (1967). Soil Chemical Analysis. Prentic-Hall, India, Private Limited, New Delhi.

Monteith, J.L. (1986). How do crops manipulate water supply and demand.Philosophical Transaction of the Royal Society, London. 316: 245-259.

Nagai, T., R. Inoue, H. Inoue and N. Suzuki (2002). Scavenging capacities of pollen extracts from Cistusladaniferus on autoxidation, superoxide radicals, hydroxyl radicals and DPPH radicals. Nutr. Res., 22: 519-526.

Naderi, M.R. and A.D. Shahraki (2013). Nanofertilizers and their roles in sustainable agriculture. Int. J. Agric. Crop Sci., 19: 22292232.

Neeraja, G., I.P. Reddy and B. Gautham (2005). Effect of growth promoters on growth and yield of tomato cv. Marutham. J. Res. ANGRAU, 33 (3): 68-70.

Olsen, S.R. and L.E. Sommers (1982). Phosphorus. In: Page, A.L.; R. H. Miller and D.R. Keeney (Eds). Methods of Soil Analysis. Part 2 Ame. Soc. Agron. Madison, W.I. USA, 403-430.

Prakash, M. and K. Ramachandran (2000). Effects of chemical ameliorants in brinjal (Solanum melongena L.) under moisture stress conditions. J. Agron. Crop Sci., 185: 237-239.

Quda, S. (2016). Major Crops and Water Scarcity in Egypt: Irrigation Water Management under Changing Climate; Springer: Cham, Switzerland; ISBN 978-3-319-21771-0.

Saleh, M.M. and M.M. El-Tantawy (2001). Water requirements and leching ratio for snap bean production under clear polyethelene low tunnels. J. Agric. Sci. Mansoura Univ., 26 (5): 3261-3270.

Saleh, S., G. Liu, M. Liu, Y. Hai, H. He and N. Gruda (2018). Effect of irrigation on growth, yield, and chemical composition of two green bean cultivars. Hort., 4 (3) 1-10.

Snedecor, G.W. and W.G. Cochran (1980). Statistial Methoods, $7^{\text {th }}$ Ed., The Iowa state Univ., Press, Ames., Iowa, USA.

Thorn, A.J. and L.M. Rogan (2015). The effects of lithovit on production and returns in a Hayward kiwifruit orchard. Grower Services Manager, 1: 1-13.

Wallace, D.H. and H.M. Munger (1965). Studies of the physiological basis for yield differences.1.growth and analysis of six dry bean varieties. Crop Sci., 5: 343-348.

WWAP (2014). United Nations World Water Assessment Programme. The United Nations World Water Development Report: Water and Energy; UNESCO: Paris, France. 
تأثير الرش الورقى بالمستخلص المائى لحبوب لقاح نخيل البلح و الليثوفيت على جودة محصول الفاصوليا الجافة تحت مستويات رى مختلفة

\author{
يسرية أحمد إبر اهيم بيان \\ أقسام بحوث الخضر ـ معهد بحوث البساتين- مركز البحوث الزر اعية ـ الجيزة ـ مصر بئن
}

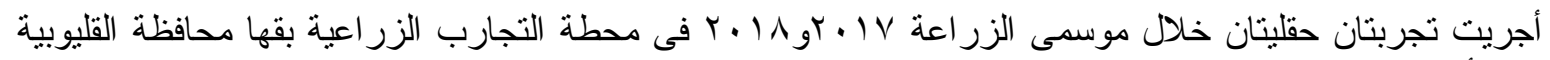

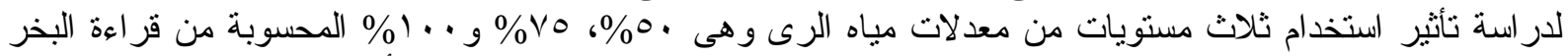

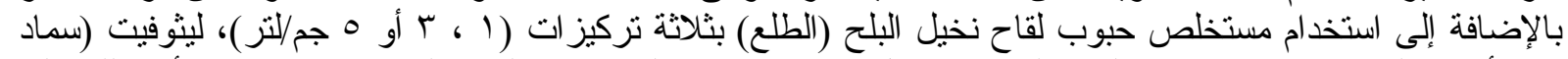

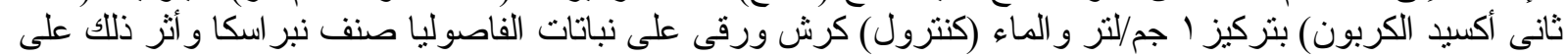

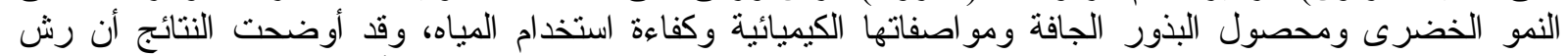

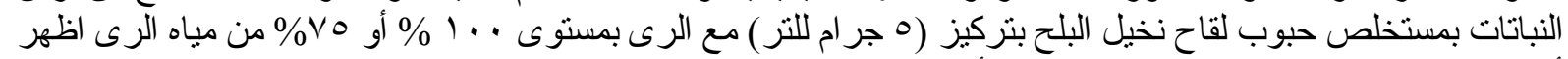

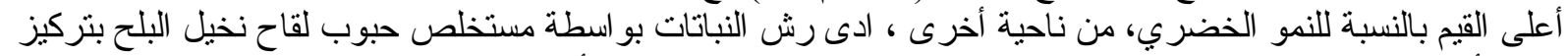

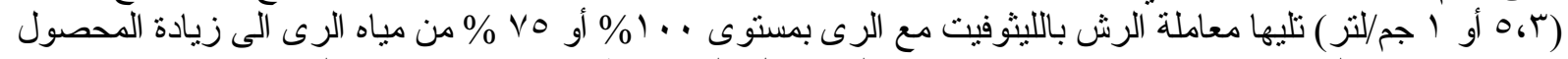

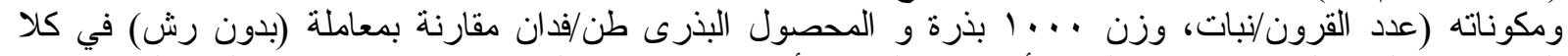

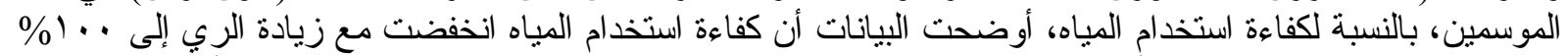

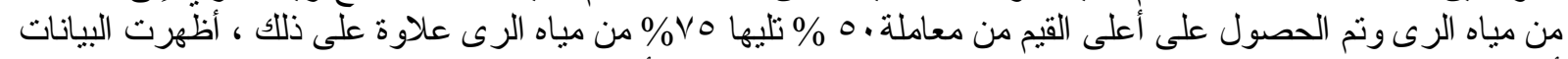

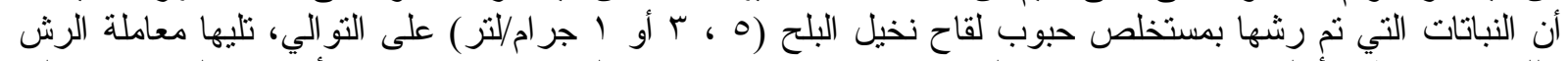

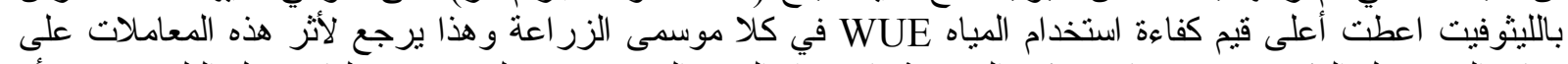

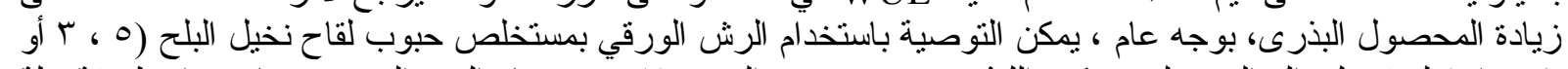

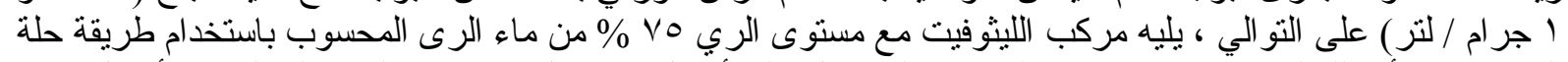

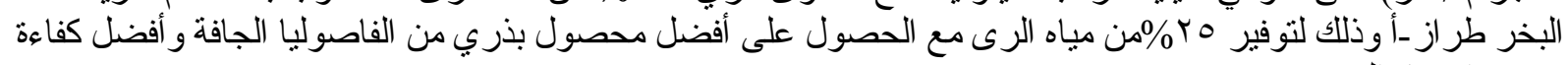
لاستخدام مياه الرى ألرى 